\title{
PEOPLE v. PROPERTY
}

Not so very long ago a developer sought to construct a high-rise apartment building in what is known as the Oliver district in the City of Edmonton. His proposal was refused by the Development Officer and he appealed this decision to the Development Appeal Board. Hannley, a resident, contested the appeal and made representations to the Board. Eventually a decision came down granting the appeal. In its decision the Board gave, inter alia, these reasons: ". . . the development will not adversely affect amenities of the neighborhood ...." The resident took an appeal to the Alberta Appellate Division, one of the grounds being that because these "reasons" were obviously couched in the very words of s. 83(3) (c)(i)(A) of the Planning Act, $1977^{1}$ (the only difference being that "adversely" replaces "unduly" as found in the Act) they did not amount to reasons as required by s. 83(2)(b). ${ }^{2}$ This section says:

The Development Appeal Board shall ... give its decision in writing together with reasons for the decision....

In Hannley v. The City of Edmonton et al. ${ }^{3}$ the Honourable Mr. Justice Sinclair (as he then was), speaking for the Court, quoted and approved this rule from Dome Petroleum Ltd. v. Public Utilities Board:4

... the section (referring to the Administrative Procedures Act, s. 8) is intended to enable persons whose rights are adversely affected by an administrative decision to know what the reasons for that decision were. The reasons must be proper, adequate and intelligible. They must also enable the person concerned to assess whether he has grounds of appeal.

The Planning Act, 1977, s. 83(2)(b) ${ }^{5}$ was similarly construed. The Court held that the Board's remarks could not amount to reasons: “. . . in adopting, word for word as it were, the provision of the legislation, the Board has stated a conclusion, but has not given reasons." The reasons must be more than a mere parroting of the words of the Act.

This decision is the latest in a series of recent Alberta cases explaining the duty to give reasons which has been imposed upon administrative boards by statute. ${ }^{6}$ Other than the Development Appeal Board and the Public Utilities Board, the Administrative Procedures Act imposes a like duty upon: The Alberta Planning Board, The Alberta Agricultural Products Marketing Council, The Board of Arbitration under the Right of Entry Arbitration Act, The Highway Traffic Board, The Irrigation Council, The Local Authorities Board, The Oil and Gas Conservation Board and The Environment Conservation Authority (when acting in certain limited capacities). ${ }^{\text {? }}$

1. S.A. 1977 c. 89.

2. The Planning Act, 1977, S.A. 1977 c. 89.

3. 7Alta.L.R.(2d)394,12A.R.473.

4. (1977) 2 A.R. 451 at 472.

5. Supra n. 1.

6. Morin and Sunbridge Investments Ltd. v.Provincial Planning Board [1974]6W.W.R. 291 Re Northwestern Utilities Limited, City of Edmonton v. Public Utilities Board (1976) 2 A.R. 317 and the Dome case, n. 4. A further case decided after Hannley is Green, Michaels and Associates Ltd. et al. v. PUB (1979) 13 A.R. 574.

7. Alta. Regs. $131 / 78,123 / 70$ and 10/74. 
There are obvious reasons why this trend is a good thing. The need to expose to the public one's reasons is a positive incentive to consider the result with greater care. Parties to the dispute will be able to ascertain whether the Board in fact comprehended the issues and arguments before it and whether the basis for the conclusions drawn contains an error of law or jurisdiction giving rise to an arguable appeal. It is difficult to gainsay the public interest in knowing why one conclusion was preferred over another.

Standing in stark contrast to this keen solicitude for judicial and quasijudicial pronouncements concerning commerce and property is the relatively recent pronouncement of the Supreme Court of Canada on the duty of the trial judge to give reasons for his decision in a criminal case: MacDonald v.The Queen..$^{8}$ MacDonald had been convicted by a Special General Court Martial of robbery and of joyriding. The facts were these: The accused, at the age of 16 years, had made an unsuccessful attempt to steal money from an army guardhouse. He had entered the guardhouse and held the guards at gunpoint, but upon being informed they had no keys to the cash box fired three shots at the radio and telephone and fled. Five minutes later he returned unarmed and surrendered to the guards without further incident. Psychiatric evidence was presented at the trial, the defence being that the accused, although not mentally diseased, deranged or defective, nonetheless was sufficiently disturbed as to be incapable of forming the intent required to support the charge of robbery. At the conclusion of a five-day trial the Court convicted the accused but gave no reasons for that finding. It was this failure to give reasons that was the basis for the appeal to the Supreme Court of Canada. Chief Justice Laskin, speaking for the majority, said this: ${ }^{\bullet}$

Mere failure of a trial Judge to give reasons, in the absence of any statutory or common law obligation to give them, does not raise a question of law. There is no such statutory obligation under the National Defence Act nor under the Criminal Code,nor can I find, or be justified in fashioning, a common law rule applicable to all criminal trials. The desirability of giving reasons is unquestionable. As was said in a note in 48 Can. Bar Rev. 584 (1970), by Professor Hooper,

The arguments in favour of reasoned judgments are obvious. The process of publicly formulating his reasons may lead the judge to a conclusion other than that reached upon the basis of "intuition". The parties to the case, both the Crown and the defence, will want to assure themselves that the judge properly understood the issues before him and will want to know whether he reached any conclusions of law or fact that could be challenged at the appellate level. The general public, or at least the victim if there was one, may have an interest in know. ing why a certain verdict was reach.

These considerations and others that could be mustered go to show what is the preferable practice, but the volume of criminal work makes an indiscriminate requirement of reasons impractical, especially in provincial criminal Courts, and the risk of ending up with a ritual formula makes it undesirable to fetter the discretion of trial Judges.

Justice Spence, although speaking in dissent, agreed with this rule so far as it applies to Provincial Judges. The Court's fundamental rationale for the refusal to impose a duty to give reasons upon trial judges, and in particular upon Provincial Court Judges, is clear: the number of cases that must be handled makes it impractical to insist upon reasons. In other words, these judges are just too busy. 
It is therefore clear that, where adjudication takes place regarding commerce and property and legal rights arising therefrom, we as a society have decided that the matters are sufficiently grave and weighty so as to merit the requirement that Administrative Boards give reasons for the actions they take. Yet where decisions are made regarding our liberty and freedom, and that of the least of our citizens, we are prepared to sacrifice the benefits of reasoned judgment on the altar of expediency.

Is this truly a reflection of those principles and priorities governing life in Canada today?

T.J. McEvoy*

D.P. Carroll ${ }^{*}$

* LL.B (U of A); Articling with the Supreme Court of Alberta and Field Owen in Edmonton.

- LL. B. (U of A); Articling with the District Court of Alberta and Braul,Gaffney, Watson and Galbraith. 
It is therefore clear that, where adjudication takes place regarding commerce and property and legal rights arising therefrom, we as a society have decided that the matters are sufficiently grave and weighty so as to merit the requirement that Administrative Boards give reasons for the actions they take. Yet where decisions are made regarding our liberty and freedom, and that of the least of our citizens, we are prepared to sacrifice the benefits of reasoned judgment on the altar of expediency.

Is this truly a reflection of those principles and priorities governing life in Canada today?

T.J. McEvoy*

D.P. Carroll ${ }^{\star}$

- LL.B (U of A); Articling with the Supreme Court of Alberta and Field Owen in Edmonton.

- LL.B. (U of A); Articling with the District Court of Alberta and Braul,Gaffney, Watson and Galbraith. 
There are obvious reasons why this trend is a good thing. The need to expose to the public one's reasons is a positive incentive to consider the result with greater care. Parties to the dispute will be able to ascertain whether the Board in fact comprehended the issues and arguments before it and whether the basis for the conclusions drawn contains an error of law or jurisdiction giving rise to an arguable appeal. It is difficult to gainsay the public interest in knowing why one conclusion was preferred over another.

Standing in stark contrast to this keen solicitude for judicial and quasijudicial pronouncements concerning commerce and property is the relatively recent pronouncement of the Supreme Court of Canada on the duty of the trial judge to give reasons for his decision in a criminal case: MacDonald v.The Queen. ${ }^{8}$ MacDonald had been convicted by a Special General Court Martial of robbery and of joyriding. The facts were these: The accused, at the age of 16 years, had made an unsuccessful attempt to steal money from an army guardhouse. He had entered the guardhouse and held the guards at gunpoint, but upon being informed they had no keys to the cash box fired three shots at the radio and telephone and fled. Five minutes later he returned unarmed and surrendered to the guards without further incident. Psychiatric evidence was presented at the trial, the defence being that the accused, although not mentally diseased, deranged or defective, nonetheless was sufficiently disturbed as to be incapable of forming the intent required to support the charge of robbery. At the conclusion of a five-day trial the Court convicted the accused but gave no reasons for that finding. It was this failure to give reasons that was the basis for the appeal to the Supreme Court of Canada. Chief Justice Laskin, speaking for the majority, said this:

Mere failure of a trial Judge to give reasons, in the absence of any statutory or common law obligation to give them, does not raise a question of law. There is no such statutory obligation under the National Defence Act nor under the Criminal Code,nor can I find, or be justified in fashioning, a common law rule applicable to all criminal trials. The desirability of giving reasons is unquestionable. As was said in a note in $48 \mathrm{Can}$. Bar Rev. 584 (1970), by Professor Hooper,

The arguments in favour of reasoned judgments are obvious. The process of publicly formulating his reasons may lead the judge to a conclusion other than that reached upon the basis of "intuition". The parties to the case, both the Crown and the defence, will want to assure themselves that the judge properly understood the issues before him and will want to know whether he reached any conclusions of law or fact that could be challenged at the appellate level. The general public, or at least the victim if there was one, may have an interest in knowing why a certain verdict was reach.

These considerations and others that could be mustered go to show what is the preferable practice, but the volume of criminal work makes an indiscriminate requirement of reasons impractical, especially in provincial criminal Courts, and the risk of ending up with a ritual formula makes it undesirable to fetter the discretion of trial Judges.

Justice Spence, although speaking in dissent, agreed with this rule so far as it applies to Provincial Judges. The Court's fundamental rationale for the refusal to impose a duty to give reasons upon trial judges, and in particular upon Provincial Court Judges, is clear: the number of cases that must be handled makes it impractical to insist upon reasons. In other words, these judges are just too busy. 